\title{
Assisted Conception Services and Regulation within the Brazilian Context
}

\author{
Sandra Garcia ${ }^{1}$, Marian Bellamy ${ }^{1}$ \\ ${ }^{1}$ CEBRAP - Brazilian Center for Analysis and Planning
}

\begin{abstract}
Objective: The aim of this article was to analyze the social, ethical, and legal aspects related to assisted conception in Brazil.

Methods: This paper was based on preliminary data extracted from research "Assisted Reproduction in Brazil: Demographic, Social Aspects and Implications for Public Poli$c y^{\prime \prime}$. This study aimed to investigate the private and public supply, the availability, and the criteria to allow access to reproductive technologies within the realms of public services, government regulations and legislation, professional association guidelines, and self-regulations, in addition to the ensuing ethical and social implications. The data comprises interviews with fertility specialists; Federal Board of Medicine resolutions on assisted conception; technical standards set by the Brazilian Health Surveillance Agency; participant observation; and detailed field notes of the Congresses of the Brazilian Society for Assisted Conception.

Results: Health care services have been unable to meet the growing demand for infertility treatment. Assisted reproductive technologies are mainly offered by private clinics at a very high cost. There is no specific legislation regulating assisted conception in Brazil. Bills aimed to regulate it are markedly influenced by religious views and moral judgment. Evangelical and Catholic members of Congress against procedures involving the manipulation of embryos hamper discussions on the topic.

Conclusions: In the absence of state regulation, resolutions of the Federal Board of Medicine are filling the gap. Regarding all reproductive rights, equitable access to assisted conception care is dependent on public health services.
\end{abstract}

Keywords: Infertility, Assisted reproductive technologies, Access, Regulation, Reproductive rights, Public health.

\section{INTRODUCTION}

Assisted conception is a significant milestone in the evolution of Biomedicine technology (Correa \& Loyola, 2005; Oliveira \& Borges, 2000; Diniz, 2003). It has grown rapidly and globally since the first child was born from in vitro fertilization (IVF) in 1978. The demand for services based on assisted conception technology has risen substantially in European countries and in the United States (Spar, 2006). One percent of the births in the United States and Western Europe derive from the use of assisted reproductive technologies, with IVF ranking atop other methods. Denmark stands out among European countries, with an annual assisted reproductive technology birth rate of five percent (Spar, 2006).

Brazil has also seen an increase in the demand for assisted conception services, which are mainly offered by private clinics at a very high cost. The growing use of reproductive technologies in Brazil has been associated, to a large extent, with the postponement of maternity until after the age of 30 (Berquó \& Garcia, 2012). Although the postponement of maternity occurs more frequently among women with higher income levels, a relevant number of less privileged women have also been choosing to become mothers at later stages of their lives (Berquó \& Garcia, 2012).

According to the literature, 70 million couples of reproductive age have trouble getting pregnant. Moreover, most of them cannot afford assisted reproductive treatments and have no access to such procedures at public clinics (Ombelet et al., 2008). In the case of Brazil, empirical studies have reported unequal levels of access to ART by low-income populations within the public health service (Makuch et al., 2010, 2011; Makuch \& Bahamondes, 2012).

Considering the milestone of reproductive rights, reproductive choices and their implementation are dependent upon the access to all reproductive planning services, including assisted reproductive technologies.

This paper aimed to analyze the ethical, normative, and legal aspects involved in assisted conception and the responsiveness of public health services to the demand for assisted reproduction treatments in Brazil.

\section{MATERIALS AND METHODS}

This paper was based on the analysis of preliminary results from the study "Assisted Reproduction in Brazil: Demographic, Social Aspects and Implications for Public Policy" covering the years of 2010 to 2014. It aims to investigate the public and private supply of reproductive technologies, availability, and access criteria adopted in public health services, government regulation and legislation, professional association guidelines and self-regulations and ethical and social consequences.

The primary data used in this paper comprises semi-structured interviews with medical fertility specialists from nine services (four public and five private services), technicians from the Brazilian Health Surveillance Agency (ANVISA) responsible for regulating assisted reproduction services, and a member of Congress rapporteur of Bill $1184 / 2003$, drafted to regulate assisted conception in Brazil. The interviews were taped and transcribed in full. They were conducted in the cities of Brasília, São Paulo, Rio de Janeiro, Belo Horizonte, Porto Alegre, Salvador, and Brasilia. The interviews covered the legal, ethical, and social aspects of assisted conception, including legislation, regulation, mandatory reporting registries, financial aspects of IVF treatment, gamete and embryo donation, surrogacy, risks of IVF treatment for women and the offspring, and unequal access to treatment.

The field notes from scientific discussions held in various Congresses of the Brazilian Assisted Reproduction Society and the Latin American Assisted Reproduction Society from 2010 to 2013 were used.

The authors attended these scientific meetings and observed the discussions between physicians and noted their views on social, ethical and legal matters. The authors took notes during the discussions and talked to participants during the breaks. Specialists from both private and public services were present at these meetings.

The secondary data comprised the analysis of regulations, resolutions, and government ordinances; resolutions by the Federal Board of Medicine regulating assisted conception practices; technical opinions is- 
sued by the Federal Board and its regional chapters.

The technical regulations published by ANVISA and the bills pending in Congress on the regulation of assisted conception were also examined.

The main issues investigated were same-sex couples, single females, HIV couples, sex selection, surrogacy, equal access to medical services, embryo transfer, exceeding embryos, gamete donation and/or compensation, public funding for IVF treatments, legislation, and regulatory registries.

The interviews were categorized based on previously defined codes. Data managing, processing, and analysis were performed with the aid of software package Atlas TI. The software package allowed the organization and selection of the material according to categories defined by the author.

\section{RESULTS AND DISCUSSION}

\section{Brazilian Health System}

Congress established the Brazilian Public Health Care System (SUS) in 1988. It was the result of the combination of popular demand and the efforts of specialized institutions in favor of the implementation of a public, tax-funded, free of charge, universal access health care system. The SUS is based upon the following principles: universality (public health should be guaranteed for all citizens); equity (in that it provides from basic to specialized care); and integrality (it implies a holistic perspective and the supply of integrated care). It is organized within a regional and hierarchical division of services, between the three levels of the Brazilian Federation - cities, states and the Federal Government - and involves public mobilization (periodical conferences and permanent counsels involving public managers, health care workers, and users of the system) (Conass, 2011a).

The three levels of government fund the system. The Federal Government is required to provide at least the same amount as the growth of the GDP of the previous year. The states are required to spend at least $12 \%$ and the cities $15 \%$ of their budgets to fund the SUS. Constitutional Amendment 29/2000, regulated by Federal Complementary Law 141/2012, defines such fund allocation. In 2012, the per capita expenditure of public funds allotted to health care in the country amounted to USD 512.60 (Global Health Observatory, 2013).

The system has been only partially able to meet these requirements. In 2011, Brazil spent in only $4.1 \%$ of its GDP on public health care according to the World Health Organization (Global Health Observatory, 2012). Another challenge is the complex coexistence of the public system with a private health care system funded through private health insurance. Even though in September 2013 25.3\% of the population had private health insurance according to the National Health Agency, people still seek the SUS for procedures of medium and high complexity (Conass, 2011b). This is not the case for assisted reproductive treatments, which are not covered by private health insurance and are offered on a limited basis by the SUS.

The SUS does not have a line in its budget to fund assisted reproductive procedures. What it has is a list of procedures reimbursed by the National Health Fund (Fundo Nacional de Saúde), the federal agency responsible for investing taxpayer money in health care directly or by transferring funds to State or Local Health Funds. Procedures not included in this list are paid for by state and local budgets.

Assisted conception procedures are not included in the list. The supply of these procedures is dependent upon the interest of local governments in funding them, which creates an unstable supply of assisted conception services.

\section{Private Clinics}

The number of private clinics offering assisted conception services in the country has increased significantly. Determining their exact number is, however, a complex task.

Clinics are required to register with the ANVISA through the National Embryo Production System (SisEmbrio). SisEmbrio was created in 2008 to record the number of human embryos produced and implanted in the country using the IVF technique - cryopreserved and research-targeted human embryos - and the potential number of embryos destined to research and therapeutic purposes.

Registration with other institutions, although existing, is not mandatory. The Brazilian Society of Assisted Reproduction, an institution organized around physicians working with assisted reproduction, is one of these entities, as is the Latin American Network of Assisted Reproduction (LARA Network) - the Latin American institution in charge of accrediting assisted reproduction clinics.

By crossing the records of these institutions and based on web searches, the authors of this paper found around 220 services currently offering assisted reproduction services in Brazil, $51 \%$ of which located in São Paulo. The IVF treatments offered by private clinics is very expensive and only higher-income populations can afford them. According to the specialists interviewed, there is no waiting list at these clinics.

\section{Public policies and services}

From the point of view of the implementation of reproductive rights, family planning has been secured by the Brazilian Constitution since 1988 (Article 226, paragraph 7) and by Law 9263/1996, which states that: "To exercise the right to family planning one will receive all methods and techniques of conception and contraception which are scientifically accepted and that do not pose risk to the lives of those involved, guaranteeing freedom of action". This Law regulates and addresses the right to reproduction for those incapable of but willing to procreate, but it does not regulate assisted conception specifically. Accordingly, it would be the duty of the State to secure such rights, by taking positive steps to prevent infertility and provide infertility treatment and enable access to techniques of assisted human conception. And to do so by providing the resources needed through the SUS following the principles of universality, integrality, and equity.

Offering infertility treatment to individuals and couples is not a priority for the Brazilian Public Health System. In March 2012, the Ministry of Health stated in the media it was establishing a technical committee to discuss the issue. One of the specialists interviewed in our study participated in the committees first meeting. The committee never issued a report from this discussion, and no further meetings were held. The director of a Public Human Reproduction Service (Hospital Regional da Asa Sul - Distrito Federal), one of the members of the Committee, stated in an interview that "currently the SUS offers 31 assisted human reproduction procedures - most of which are preliminary tests for treatments of higher complexity, such as in vitro fertilization."

This study found that by mid-2012 only nine public institutions were offering IVF treatment, four of which at no charge and five charging partially for the procedures ${ }^{(1)}$.

A study conducted by Samrsla et al. (2007) on the assisted reproduction services offered by the Hospital Regional Asa Sul de Brasília showed that the waiting lines were very long and that patients were not informed about 
how long they would have to wait for procedure, which, on average, was four years. Makuch et al. (2011) addressed the inequality of access and the long waiting times in the assisted reproduction services offered by the Hospital da Universidade Estadual de Campinas. Complex treatments are no longer offered at this center, which today offers solely low complexity procedures.

These findings were corroborated by the interviews conducted with the physician in charge of the public service at Hospital Regional da Asa Sul and with the physician in charge of the public services offered by the Hospital Pérola Byington in São Paulo. Both reported high levels of demand and lack of service capacity:

"Currently there is a four-year waiting line. And it could take longer, but let's say it's four years. So what did we do? This year, what did we do? We stopped scheduling new appointments because we wanted to end the waiting line". (Director of the Human Reproduction Center at Hospital Regional da Asa Sul)

The Human Reproduction Center of the Hospital das Clínicas de São Paulo also offers services of low, medium, and high complexity. This center was reopened in July 2011, after having been closed in 2007 due to a fire in one of its facilities. According to its director, the Center was improved to meet the new standards of the ANVISA. However, only patients aged 38 or younger will be offered treatment.

"The decision was approved by the ethics committee of the Hospital das Clínicas, because as of this age the chances of getting pregnant are reduced to less than 5\% due to the poor quality of the eggs. In 2003, when the Center was opened, there was no age limit, and more than half of the 8,000 women enrolled were over 40 . The service is going to be $100 \%$ public. Couples will be sent for treatment by the SUS health care unit. All costs will be paid by the State Government." (Director of Center for Reproduction, Hospital das Clínicas, São Paulo)

According to the interviewee, the Hospital Regional da Asa Sul of Distrito Federal has no exclusion criteria based on sociodemographic criteria or an age limit for patients:

"There is no age limit. If the patient starts at the age of 41, in five years' time she will be 46. The criterion is clinical judgment. We tell the patient: Look, it is going to take three years. The patient arrives at 45. You will wait for three years. And what you will probably hear from me when you arrive for treatment is you are no longer fit to do it. I will evaluate your follicular potential and you will have none. Patients are warned, but none is excluded due to age. We raise awareness and tell patients they should not wait, but we will not exclude them" (Director of Human Reproduction Center, Hospital Regional da Asa Sul). Nevertheless, infections such as hepatitis and HIV are also considered to be exclusion criteria by the Hospital Regional da Asa Sul-DF due to the nonexistence of separate machines for procedures performed in these patients as required by the ANVISA.

It should be noted that despite the lack of an age limit, women seeking assisted reproduction therapies who have to wait for four years will be that closer to menopause by the time they are offered treatment. And such delay affects the chances of successful treatment.

The person in charge of the service at Hospital Pérola Byington shared a different perspective on the age limit issue:

"The patients admitted until last year had no age limit imposed upon them; an age limit has been applied since, so now we see patients aged 35 years or younger. Considering that patients have to wait for four years, a patient that age will be 40 when treated." (Director of Human Reproduction Center, Hospital Pérola Byington)
The interviewee in charge of Hospital Pérola Byington in São Paulo also mentioned exclusion by clinical criteria due to the service's inability to treat patients with severe diseases:

"And we cannot accept patients with severe diseases, heart diseases, severe hypertension, and patients with spreading diabetes. This is also debatable because many of these patients, despite being sick, have the right to treatment. I would even understand this if I were in a hospital where I had a general practice or an obstetrics clinic, and a patient with severe heart disease came to me. I would discuss the issue in a meeting, talk to the general practitioner and the obstetrician, and I would tell them: I will offer her treatment. Would the general practitioner agree? Would they handle the treatment? Would the obstetrician do the prenatal screening? Would they handle it? Would we all be committed to treating this woman? Yes, we would. If this were the case I would do it. But I am in a hospital in which I fertilize the woman then send her to prenatal screening somewhere else. So, I do not". (Director of Human Reproduction Center, Hospital Pérola Byington)

This interviewee cited another relevant issue: procedures involving gamete donation were not included in the hospital's budget, and therefore are not performed. This restriction affects everyone in need of gamete donation - heterosexual couples included - and constitutes an obstacle to the treatment of single people and homosexual couples in particular.

Yet, none of the interviewees reported the existence of obstacles of a "social" nature in the access to the procedures, i.e., treatment is also offered to single women and homosexual couples. The few existing public services impose restrictions to patients based on their age at the start of treatment and on whether they are HIV-positive. Budget was named the most significant restriction to the supply of complex assisted conception treatments at public services.

The service at Hospital Regional da Asa Sul often relies on the personal efforts of its administrators:

"And that is when the patients resort to whatever they can, you see? Sometimes I will help, I will give them money. I feel really sorry for them (...)." (Director of the Center for Reproduction, Hospital Regional da Asa Sul)

This administrator mentioned the hospital was funded with resources coming from the Distrito Federal state budget, not the Federal budget; and added that the very limited funds the hospital receives are not transferred regularly.

"So far the SUS has not included fertility treatment in its list of reimbursed procedures. Our funds come from the State budget. So it's the Public Health State Funding that supports them."

The interviewee also alluded to a sperm function test that cannot be conducted at the hospital. She did not mention the number of people in need of such test, but stressed she often calls her friends at private services to ask for help:

"(...) I call them and say: can you please do it for a lower price? See what you can do for me (...) And since we are good friends, they manage to help."

The situation at Hospital Pérola Byington in São Paulo is more stable. In spite of being also funded by a State budget, there is a fixed amount assigned to the Hospital for assisted conception procedures. The hospital has managed to receive a specific and regular budget for human reproduction thanks to previous administrators.

Although infertility prevention is a significant portion of reproductive health care, there are no campaigns on the issue directed to the population or to young people in particular. Sometimes infertility results from untreated asymptomatic sexually transmitted diseases. 
Strategies to lower the costs of the procedures were also mentioned. In an interview conducted at a not-forprofit assisted conception service center in the city of Santo André, in the state of São Paulo, linked to the Medical School of the ABC Region (Faculdade de Medicina do ABC), IVF procedures are offered for approximately a third of the price charged by private clinics in general. This was made possible thanks to price negotiations with the pharmaceutical industry. Government does not control the prices of pharmaceuticals in Brazil.

Many are the challenges inherent to the development of public policies to allow greater access to reproductive technologies, the preparation and implementation of guidelines to establish assisted reproduction services in the country, and the determination of a budgetary framework for the public health system. In late December 2013, the federal government published an ordinance setting aside BRL 10 million to be distributed among eight public centers offering infertility treatment. However, the distribution criteria and how these funds will be used by these centers are still unclear(2).

\section{Regulation}

Assisted conception has been the topic of study of several researchers in Brazil. Some of them emphasized the lack of regulation for this practice (Correa \& Loyola, 2005; Medeiros \& Verdi, 2010), while others were concerned about the complex ethic and moral issues related to dealing with embryos (Correa \& Loyola, 2005; Diniz, 2001; Guilherm, 2000), such as anonymity when donating gametes and the medical manipulation of the female body (Tamanini, 2004; Correa, 1998). Diniz (2001) and Correa (2000) studied the first resolution by the Federal Board of Medicine in 1992 concerning the ethical norms for the utilization of such technologies. The latest resolution was published in December 2013 (CFM, 2013). There is not yet any published analysis of the changes introduced by it.

On the other hand we lack empirical studies with information about the performance of both sectors in this area and about the decisions of Federal and Regional Boards of Medicine on cases not described in these resolutions. Ultimately, the resolutions and the set of written opinions released by the Boards have been fulfilling the legal void prevailing in Brazil.

In January 2005, the Biosecurity Law set the standards for the use of genetic engineering techniques. It condemned the manipulation of human germ cells, thereby taking precautions against cloning and eugenics, and established the National Biosecurity Board.

Permission is subject to the following conditions: 1. Embryos have to be viable or. 2. Embryos must have been frozen for over three years as of the date of the enactment of the Law, or 3.Embryos must be frozen as of the date of enactment of the Law, after having completed three years, as of the date they were frozen. In any case, the couple has to approve the use of the embryos. It also defined that "institutions for health care research and services that conduct research on or therapy with human embryo stem cells must submit their projects to the examination and approval of the respective committees on research ethics."

Regardless of controversy, the Biosecurity Law enabled significant progress in the Brazilian legal system, which lacks specific laws and regulations designed for technological advances in medicine.

The only specific regulations in force concerning the supply of assisted conception services are the regulations set by ANVISA (Resolution 23/2011 of the Collective Board of Directors), but they are restricted to sanitary issues, such as the definition of the correct temperature to preserve sperm and eggs and to ensure that all medical and laboratory procedures done in the clinics have been registered, and the Resolutions set by the Federal Board of Medicine. However, these resolutions have no force of law, although violators are punishable.

\section{Bill discussions and the interests involved}

There are few Bills on this matter. In the Legislative process, bills must first be analyzed and approved by both Houses by a simple majority to be then to the President to be sanctioned or vetoed.

Our analysis of the Bills on reproductive technologies revealed that 16 were submitted from 1993 to 2010, 11 of which attached to current Bill - PL- 1184/2003. This Bill, already approved by Senate in 2003, is awaiting voting in the Committee on Constitution and Justice (CCJ) in Congress, before going to the full chamber. The Bill, aimed at regulating assisted conception in Brazil, includes in its determinations the limitation to a maximum of two embryos implanted in each IVF cycle and a ban on embryo freezing.

Religious influence is present in all proposals. Although government in Brazil is officially secular, Catholics and Evangelicals amount to $65 \%$ and $22 \%$ of the population, respectively (IBGE, 2012). In Congress there is a strong alliance between these groups in topics related to family issues, abortion, and sexuality. Organized religious groups also try to veto high-complexity assisted conception procedures in which gametes or embryos are manipulated. To accomplish this, a catholic caucus with members of Congress from all parties acts with the support of the $\mathrm{Na}$ tional Conference of Bishops of Brazil to lobby against reproductive rights. Evangelicals (also organized in a group in Congress) discuss and vote with Catholics in sensitive issues involving assisted conception, abortion, and embryo research, among other matters.

Assisted conception has been recurrently associated with abortion, which is another sensitive issue for religious groups. This association is made because not all produced embryos are saved. This became evident during the interviews conducted in Brasília with a Congress member, the rapporteur of Bill 1.184/2003. Abortion was one of the reasons why the rapporteur asked to be placed in charge of Bill 1.184.

This rapporteur is also the leader of the evangelical caucus in Congress. In voting sessions concerning the interests of both religious groups, party differences are left aside. This became evident in the interview with the evangelical member of Congress:

"When the access to an embryo bank was included in Article Five, we, catholic and evangelical members of Congress, became aware of the issue. Well, we are 300 (...) It's 20 active members, plus another 77, which brings us to close to 100. Seventy-seven are evangelicals. (...) And we are personally against the bill, all of it".

An assistant to the National Conference of Bishops of Brazil acting at Congress said: "As a Catholic, I am against the bill. We always prefer adoption. But because we know that clinics are a reality, they do exist, there is the need for regulation. This is what we believe: the stricter the regulation, the fewer frozen embryos will be disposed of. We advocate the thesis that life begins at conception. And since this is what we believe in, we will stick by it."

Regardless of the discussions on the influence of religious groups in the legislative process - which involve the contemporary debate on the secular nature of the Brazilian Government - the Bills, which still need the approval of Congress, have been under scrutiny for a long time, not only due to their controversial characteristics but also because they do not provide political divi- 
dends such as positive media exposure or votes, an impression confirmed by the rapporteur and his assistants.

\section{Federal Board of Medicine (CFM) Resolutions and technical opinions by the Federal and Regional Boards (CRM): filling the gap}

The most recent Resolution (CFM 2.013/2013) regulates the disposal of embryos, shared egg donation, and age limits for egg donors ( 35 years), semen donors (50 years), and for women to submit to assisted conception (50 years). It also extended to a fourth degree relative the permission for surrogacy arrangements and explicitly determined the right of single individuals and homosexual couples to opt for assisted conception.

In order to understand the demands and discussions concerning the cases that do not fall under the CFM Resolution, we looked into the technical opinions over requests for ethical-legal analyses published in the websites of the Federal and Regional Boards of Medicine (CRMs).

The 50 different opinions analyzed cover the period from 1997 to 2011, before the latest resolution was issued in 2013. The main themes addressed were: surrogacy, egg donation, semen donation, assisted fertilization for individuals with HIV, sex selection, destination of preserved embryos, transfer of embryos, informed consent process, installation and functioning of clinics, and assisted conception for homosexual couples. Twenty-two of the 50 opinions were issued by the CRM of the State of São Paulo, the state with the largest number of assisted conception services in Brazil.

The requests show the level of complexity concerning assisted conception issues, as well as the ethical, moral, and legal aspects involved in the inquiries. For instance, some physicians advocated the payment to egg donors as a way of compensating for the invasive procedure they undergo and to address the issue of egg shortage. This procedure was not allowed by the CFM resolution.

However, the most recurring theme was "surrogacy", present in 16 issued opinions. Before 2013, the CFM resolution allowed surrogacy only between relatives up to second degree, but set that the CRMs should decide on the cases that did not fall under this rule. Brazil has been trying to impose ethical standards to prevent human body trade, i.e., the surrogate mother cannot be paid, and that is why emphasis is given to family ties. Thirteen of the 16 opinions mentioned above discussed requests for surrogate pregnancy of up to second degree. Nine of the 13 requests were approved in several states of Brazil. In the cases in which the surrogate mother was not a relative of up to second degree, the affective connection between the genetic and the surrogate mother was used to justify the procedure.

Two requests analyzed by the CRM of the state of Goiás involved egg donation and in both cases the donors were relatives. This reflects an ethical issue for the physician, since the CFM resolution is clear with regard to the need of keeping the donors anonymous. In one of these cases, a 52 year-old woman requested in 2002 authorization to receive the eggs of her 25-year-old niece. This case was taken to the CFM. The request was denied based on the CFM Resolution of 1992, which did not allow donors and recipients acquainted with each other

Four years later, the CRM of the state of Goiás decided otherwise on a very similar case - an egg donation between sisters. Although the provisions stated that donors could not know the identity of the recipients and vice-ver$\mathrm{sa}$, the opinion authorized the procedure, as there was an agreement inside the family that included the couple donating.
Egg donation is a serious issue due to the small number of donors available. This issue is frequently debated in assisted conception meetings and the opinions on and solutions for the shortage of donors are diverse. Some physicians advocate payment to egg donors as a way of compensating for the invasive procedure they undergo and to solve the issue of egg shortage. Such opinions show the level of complexity concerning assisted conception issues, as well as the ethical and legal aspects involved in the inquiries.

It is well known that most physicians are against laws to regulate the practices within this field. Their main argument is that this would be a legal straightjacket for practices in this field, since it does not contemplate the technology advances and scientific discoveries in the area.

In this manner, they argue that the CFM resolutions and technical opinions are sufficient to regulate and hinder unethical practices. However, users still have no legal grounds to protect their rights.

\section{CONCLUSION}

The Federal Constitution of 1988 introduced a new approach to health care in Brazil.

Law 9263/1996 regulated family planning and made it mandatory for the Government to provide support to conception by "offering all methods of contraception and conception techniques that are scientifically accepted."

Hence, we ask these questions: should the Government implement a National Policy for Assisted conception that is $100 \%$ publicly funded? If assisted conception care is to be provided in full, can it include some population groups while leaving other groups out? What kind of government regulation should be addressed? Should we have a specific law for assisted conception?

These issues need to be considered in order for truly universal care to be implemented under the auspices of the principles proposed by the SUS.

Currently, the demand for assisted reproduction services is served without the basis of legal regulation, with the Boards of Medicine acting as legislators. On the other hand, the strong religious pressure that dominates the discussions in Congress has become an obstacle to the passing of legislation to regulate the practice, since decisions oriented by religious belief and values might violate the patients' constitutional rights.

Several points addressed herein deserve to be broadly discussed by society. For instance, should payment to egg donors be allowed in order to resolve the problem of the small number of donors available?

Considering the context of public health policies in Brazil and within the framework of reproductive rights, it is crucial to develop strategies to increase accessibility to reproductive technologies taking into account women's and children's health. It is also crucial to develop and provide public information and education on infertility prevention and sub-fecundity as a means to build the awareness over the risk factors for infertility. For that matter, health providers should be trained to promote prevention and provide information on this topic.

Finally, it is a political, economic, and ethical challenge for policy makers to decide how to allocate funds for assisted conception considering the universal access and free-of-charge nature of the Brazilian health care system. At present there is no open debate in the society. This enormous challenge should bring together social scientists, bioethics scholars, jurists, physicians, and policy makers in an initiative to discuss ethical and legal parameters, impacts and dilemmas, and to articulate a policy agenda to better meet peoples experiences, needs, and rights. 


\section{Acknowledgements}

The Research was supported by a grant from FAPESP (Fundação de Amparo à Pesquisa do Estado de São Paulo) in São Paulo, Brazil (Process No. 2009/14981-8).

I am grateful to Karin de Russy for valuable research assistance and for the first version in Portuguese of this paper.

\section{CONFLICT OF INTERESTS}

No conflict of interest have been declared.

\section{Corresponding author:}

Sandra Mara Garcia

CEBRAP - Brazilian Center for Analysis and Planning

São Paulo, SP - Brazil

E-mail: smgar@uol.com.br

\section{REFERENCES}

Berquó ES, Garcia SM. Algumas Considerações sobre a Reprodução Tardia no Brasil. In: Turra C M, da Cunha JMP, eds. Segunda transição demográfica no Brasil? Significados e enigmas. População e desenvolvimento em debate: contribuições da Associação Brasileira de Estudos Populacionais. Belo Horizonte: Abep; 2012. p. 135-40.

CFM Federal Board of Medicine. Resolution CFM 1.358/1992 Normas éticas para a utilização das técnicas de reprodução assistida. Diário Oficial da União. Brazil. 19 de novembro de 1992.

CFM Federal Board of Medicine. Resolution CFM 2013/2013 Normas éticas para a utilização das técnicas de reprodução assistida. Diário Oficial da União. Brazil. 9 de maio de 2013.

Conass. Para entender a gestão do SUS 2011 (Volume 1 - Sistema Único de Saúde). Brasília: Conass; 2011a. Available at: http://www.conass.org.br/biblioteca/

Conass. Para entender a gestão do SUS 2011 (Volume 12 - Saúde Suplementar). Brasília: Conass; 2011b. Available at: http://www.conass.org.br/biblioteca/

Correa MV, Loyola MA. [Reproduction and bioethics. The regulation of assisted reproduction in Brazil]. Caderno CRH. 2005;18:103-12.

Correa MV. [New reproductive technologies: oocyte donation. What could be new in this field?] Cad. Saúde Publica. $2000 ; 16: 863-70$.

Correa, MV. Novas Tecnologias Reprodutivas: bem-vindas reflexões feministas. Rev. Estud. Fem. 1998; 6:126-37.

Diniz D. Novas Tecnologias Reprodutivas, Ética e Gênero: o debate legislativo no Brasil. In: Pessini $\mathrm{L}$, Barchifontaine $\mathrm{CP}$, eds. Bioética: Al- guns Desafios. São Paulo: Loyola; 2001. p.203-24.

Diniz D. Tecnologias Reprodutivas Conceptivas: o estado da arte do debate legislativo brasileiro. JBRA Assist Reprod. $2003 ; 7: 10-9$.

Global Health Observatory. Available at: http://www.who. int/gho/countries/bra/en/ Accessed: 12/06/2012.

Guilherm DE. Novas Tecnologias Reprodutivas, Ética e Legislação no Brasil: um debate adiado. Série Anis. Brasília: Letra Livres, 2000.

IBGE Instituto Brasileiro de Geografia e Estatística. Censo Demográfico 2010. Resultados gerais da amostra. 2012.

Makuch MY, Bahamondes L. Barriers to access to infertility care and assisted reproductive technology within the public health sector in Brazil. Facts Views Vis Obgyn. 2012;4:221-6.

Makuch, MY, Simônia de Padua K, Petta CA, Duarte Osis $\mathrm{MJ}$, Bahamondes L. Inequitable access to assisted reproductive technology for the low-income Brazilian population: a qualitative study. Hum Reprod. 2011;26: 2054-60.

Makuch, MY, Petta CA, Osis MJ, Bahamondes L. Low priorities level for infertility services within the public health sector: a Brazilian case study. Hum Reprod. 2010;25: 430-5.

Medeiros LS, Verdi MI. [Right of access to the assisted human reproduction: bioethics discussions]. Cien Saude Colet. $2010 ; 15: 3129-38$.

Oliveira DC, Borges E Jr, eds.. Reprodução Assistida: até onde podemos chegar? compreendendo a ética e a lei. Sao Paulo: Editora Gaia; 2000.

Ombelet W, Cooke I, Dyer S, Serour G, Devroye P. Infertility and the provision of infertility medical services in developing countries. Hum Reprod Update. 2008; 14:605-21.

Samrsla M, Nunes JC, Kalume C, da Cunha AC, Garrafa V. [Bioethical study on the expectations of women awaiting assisted reproduction in a public hospital in the Federal District, Brazil]. Rev Assoc Med Bras. 2007;53:47-52.

Spar DL, ed. The baby business: how money, science, and politics drive the commerce of conception. Boston: Harvard Business School Press; 2006.

Tamanini M. [New reproductive conception technologies: bioethics and controversies]. Rev Estud Fem. 2004, 12: 73-107. 